\title{
Judgment of the Awareness' Towards Work-related Injury among Endodontic Staff at Selected Dental Clinics, Saudi Arabia
}

\author{
Dr. Suhail Abdlurahman Alamoudi ${ }^{1}$, Dr. Emad Hussain Habib Allah ${ }^{2}$ \\ ${ }^{1}$ General Dentist, King Fahad Hospital, Almadina, KSA \\ ${ }^{2}$ General Dentist, Ministry of Health, KSA
}

\begin{abstract}
Background: Regardless of the distinction on safety measures in health care facilities, the alternatives of organizations have measured the degree to which safety is a premeditated precedence and culture sustains patient safety. In retort to the Institute of Medicine's report and to an organizational commitment to patient guard was held an effective evaluation of safety standandrs indicators. Objective: To appraise the level of awareness' towards work-related injury among endodontic staff at Selected Dental Clinics, Saudi Arabia. Method: A cross-sectional survey was conducted at dental Clinics, Saudi Arabia. A 32 items self-administered questionnaire was provided to 100 endodontic staff in the research setting based on To evaluate the level of awareness' towards workrelated injury among endodontic staff at Selected Dental Clinics, Saudi Arabia. Results: This study showed that awareness towards the aspects of work related injury among some dental staff working at the dental clinics of the selected setting was variable. The majority (86.0\%) of the dental staff had a high level of awareness towards "HCWs with non intact skin should not be involved in direct patient care until the condition resolves". Followed by (82.0\%) at the item of "Isolation is necessary for patients with blood-borne infections". Conversely (62.0\%) of the dental staff had a low level of awareness towards work-related injury was in item "Universal precautions are not necessary in situations that might lead to contact with saliva". Conclusions: The current study results revealed that there was a high level of work related injury within the study setting.
\end{abstract}

Keywords: Judgment, Work-Related Injury; Awareness; \&Endodontic

\section{Introduction}

Ever more, healthcare facilities are fetching considerate of the insinuation of transforming organizational background in order to expand the standardized criteria \& indicators of patient safety. On the increase attention on safety traditions has been associated by the need for appraisal evaluation criteria paying awareness on the cultural essentials of continuing safety development efforts. Job-related safety culture appraisal could be applied as a instrument for enhancing patient safety. This could also exemplify the characteristics of culture appraisal tackles currently obtainable and discusses their existing and possible utilization, including brief utilization that contain assume as appraisal tools. (Jawaid, et al., 2009).

Work- related elements include explicit suggestion for utilize of personnel protective equipments (PPE) when create contact with blood and body fluids hold blood is expected Health care staff is at risk of acquiring . (Haddad, et al., 2002).

Contamination from side to side proficient experience to infectious syndrome. Entire precautions were primarily developed in 1987 by the Centers for Disease

Control and Prevention in the United States and in 1989 by the Bureau ofCommunicable Disease Epidemiology in $\mathrm{Ca}$ nada. The minority studies have reported on surgeons' adherence towards universal precautions and reported be deficient in of adequate practices in relation to fulfillment towards the personnel protective equipments (PPE). (Norden, C, Rockwell K, Hruska, T, 2008).
Health hazards are predictable to manipulate explicit risk for all the health care providers. All the health care personnel in particular the dental staff who is working in surgical units and Operation Theater are more required to have a cause of a better understanding in adherence with PPE usage which is noteworthy as it provides an assessment of the efficacy of accessible preventative strategies. This could then assist to recognize the precautionary variables which are likely to improve the compliance and decrease the risk of infection transmission. Then, it is possible to integrate these anticipatory approaches into the strategies of health care surroundings. ( Wilczyn, et al., (2005).

Policies of safety measures of work related universal precaution is the only approach so that all these infections could be prevented. Inadequate experience of surgeons in performing invasive procedures, they are at particular risk of exposure to blood-borne pathogens (Chopra, et al., 2008). Surgeons' should have reasonable knowledge and performance in relation to adherence to personnel protective equipments. Moreover, dedicated training must be conducted before a surgeons caring for any patient procedure particularly the ones concerning sharp devices. Physicians' compliance towards the personnel protective equipments has been reported to be with little level. (Elliott et al., (2005).

Taneja, (2010), reported that, risks caused by non adherence to universal precautions by the health care providers, statistics reported by the Central Register of Occupational Diseases in Poland indicates that among 314 new cases of occupational diseases in HCWs in 2004-2006, 


\section{International Journal of Science and Research (IJSR) \\ ISSN (Online): 2319-7064}

Index Copernicus Value (2016): 79.57 | Impact Factor (2015): 6.391

HBV and HCV represented $42.6 \%$ for $2004,32.5 \%$ for the year 2006 of all cases. 9 Despite the substantial reduction in HBV infection since vaccination was introduced in 1989 , the incidence of HCV hepatitis in Poland is still on the increase in this occupational group.

Policies of work related injury augment consciousness education has not been well-known among health care workers especially the category of surgeons, particularly in developing countries. To the maximum of our understanding, the attentiveness of dental staff in relation to knowledge and awareness about policies work related injury. Consequently, conducted this study to judge their level of awareness of dental staff toward work related injury at the selected dental clinics-Saudi Arabia.

\section{Participants and Methods}

This study was applied in the selected setting, and ethical approval was granted by the selected dental clinics. The number of sample size was 100 dental staff was recruited for the study. The participants were selected from the clinics. After signing an informed written consent form, the questionnaire was given to each contributor.

Previous to administration of the questionnaire, the purpose of the study was explained to each respondent and confidentiality of the information guaranteed. Sorra, (2013), reported that, the current $r$ study was carried out by one of the authors who were appropriately trained in administering the informed consent and the self-report questionnaire to the participants. In this cross-sectional study, a structured questionnaire prepared by the authors, was given to the participants.

A self-administered structured questionnaire about knowledge and awareness work related injury was devised and tested. It included a full range of response options, designed to identify the practitioner's level of to assess their level of attentiveness towards policies among dental staff in the selected setting. Prior to distribution of the questionnaire, a pilot study was done on a selective group of health care workers who were asked to fill out the questionnaire and return it back with their remarks and criticism. Minor changes were then made to the final tool.

The introduction part of the questionnaire consisted of demographic information such as occupation, age, gender, and the marital status. The second part of the questionnaire comprised of questions regarding their level of attentiveness towards universal precautions. This part also assessed the level of awareness of the dental staff toward work related injury within the study setting. It obtained within approximately 20 minutes to complete each appraisal. The level of awareness of the dental staff toward work related injury within the study setting by examining questions about: use of protective equipments' such as gloves and gown, mask and protective goggles. A score of "1" was assigned for a correct answer and " 0 " for an incorrect answer. A health care worker who obtained a total score of " 5 " was considered "very attentive;" "4 or 3" "somewhat attentive;" and "1 or 0" "not attentive."The data were coded and analyzed by SPSS $\AA$ for Windows ${ }^{\circledR}$ ver. 12.0. Strict confidentiality was maintained. All the data were stored in computers at a secured location, with access provided only to the researchers involved in the study. The $\chi 2$ test was used to test association between categorical variables. A p value $<0.05$ (two-tailed) was considered statistically significant differences.

\section{Results}

\section{Level of Awareness' towards Work-Related Injury among Dental staff at Dental Clinics of Selected Setting}

\begin{tabular}{|c|c|c|c|c|c|c|}
\hline $\begin{array}{c}\text { Items of } \\
\text { Occupational } \\
\text { Injury }\end{array}$ & \multicolumn{2}{|c|}{$\begin{array}{c}\text { Very } \\
\text { Knowledgeable }\end{array}$} & $\begin{array}{c}\text { Somewhat } \\
\text { knowledgeable }\end{array}$ & \multicolumn{2}{|c|}{$\begin{array}{c}\text { Not } \\
\text { Knowledgeable }\end{array}$} \\
\cline { 2 - 6 } & No & $\%$ & No & $\%$ & No & $\%$ \\
\hline $\begin{array}{c}\text { Universal } \\
\text { precautions are } \\
\text { applied to patients } \\
\text { with HIV and } \\
\text { viral hepatitis } \\
\text { only" }\end{array}$ & 86 & $86.0 \%$ & 4 & $4 \%$ & 10 & $10.0 \%$ \\
\hline $\begin{array}{c}\text { "Isolation is } \\
\text { necessary for } \\
\text { patients with } \\
\text { blood-borne } \\
\text { infections" }\end{array}$ & 79 & $79 \%$ & 5 & $5.0 \%$ & 16 & $16.0 \%$ \\
\hline $\begin{array}{c}\text { Used needles can } \\
\text { be recapped after } \\
\text { giving an } \\
\text { injection" }\end{array}$ & 76 & $76.0 \%$ & 14 & $14.0 \%$ & 10 & $10.0 \%$ \\
\hline $\begin{array}{c}\text { For } \\
\text { decontamination } \\
\text { of devices (with } \\
\text { only contact with } \\
\text { skin) washing } \\
\text { with usual } \\
\text { detergent is } \\
\text { enough" }\end{array}$ & 82 & $82.0 \%$ & 12 & $12.0 \%$ & 11 & $11.0 \%$ \\
\hline $\begin{array}{c}\text { Universal } \\
\text { precautions are } \\
\text { not necessary in } \\
\text { situations that } \\
\text { might lead to } \\
\text { contact with } \\
\text { saliva" }\end{array}$ & 67 & $67.0 \%$ & 13 & $13.0 \%$ & 20 & $20.0 \%$ \\
\hline $\begin{array}{c}\text { "HCWs with non } \\
\text { intact skin should } \\
\text { not be involved in } \\
\text { direct patient care } \\
\text { until the condition } \\
\text { resolves " }\end{array}$ & 72 & $72.0 \%$ & 15 & $15.0 \%$ & 13 & $13.0 \%$ \\
\hline $\begin{array}{c}\text { Blood spills } \\
\text { should be cleaned } \\
\text { up promptly with } \\
\text { sodium } \\
\text { hypochlorite" }\end{array}$ & 81 & $81.0 \%$ & 13 & $13.0 \%$ & 12 & $12.0 \%$ \\
\hline
\end{tabular}

This study showed that awareness towards the aspects of work related injury among some dental staff working at the dental clinics of the selected setting was variable. The majority $(86.0 \%)$ of the dental staff had a high level of awareness towards "HCWs with non intact skin should not be involved in direct patient care until the condition resolves". Followed by $(82.0 \%)$ at the item of "Isolation is 


\section{International Journal of Science and Research (IJSR) \\ ISSN (Online): 2319-7064}

Index Copernicus Value (2016): 79.57 | Impact Factor (2015): 6.391

necessary for patients with blood-borne infections". Conversely $(62.0 \%)$ of the dental staff had a low level of awareness towards work-related injury was in item " Universal precautions are not necessary in situations that might lead to contact with saliva" .

\section{Discussion}

The total the selected health care workers fully completed the questionnaire, giving a response rate of $100 \%$. This study showed that awareness towards the aspects of work related injury among some dental staff working at the dental clinics of the selected setting was variable. The majority $(86.0 \%)$ of the dental staff had a high level of awareness towards "HCWs with non intact skin should not be involved in direct patient care until the condition resolves". Followed by $(82.0 \%)$ at the item of "Isolation is necessary for patients with blood-borne infections". Conversely $(62.0 \%)$ of the dental staff had a low level of awareness towards workrelated injury was in item "Universal precautions are not necessary in situations that might lead to contact with saliva"

It is crucial that health care providers have high-quality understanding about the risk of blood-borne pathogens at work place and about the preventive measures for reducing risk. In this study, the majorities of the respondents were very knowledgeable of the harmful effects of bloodborne pathogens and identified HIV as a potential harm followed by hepatitis and bacterial infections. In this study, health care workers employed in the health sector for longer periods were more aware of universal precautions compared with those who served for shorter periods. Training and education have been found to be of paramount importance to developing awareness among health care workers, as well as improving adherence to high-quality clinical practice.29,30 The greater awareness of the policies of work related injury among health care workers employed for a longer period at the dental clinics of the selected setting may reflect their participation in a greater number of training and educational sessions on universal precautions which not only encouraged safer work practices but also improved concordance with policies and procedures work related injury .

Personnel Protective barriers reduce the risk of exposure of the health care worker's skin or mucous membranes to potentially infectious materials. Protective barriers reduce the risk of exposure to blood and other body fluids to which universal precautions apply. Examples of protective barriers include gloves, gowns, masks, and protective eyewear. Just over one half of the respondents indicated that they were provided with protective equipment most times. Additionally, more staff was provided with protective equipment than medical technologists and medical doctors. Interestingly, more respondents who were aware of universal precautions reported being provided with protective equipment more often than those who were somewhat or not aware. This study results congruent with the research data carried out by Kuo, et al ., (2010), who reported that less than two-thirds of health care workers claimed that they always used personal protective equipment such as aprons, gowns and gloves, during surgeries and while conducting deliveries. According to Jawaid, et al, among medical doctors working in a tertiary care hospital in Pakistan, compliance for hand washing was $86 \%$, for wearing gloves was $69 \%$, masks $46 \%$, eye goggles $32 \%$ and for using gowns/plastic aprons was $68 \%$. However, there is sometimes a high rate of non-compliance among health care workers and this may be due to a lack of understanding among health care workers of how to properly use protective barriers. Furthermore, non-compliance among medical doctors and nurses are associated with insufficient knowledge, workload, forgetfulness, workplace safety and the insight that colleagues also failed to track.

The current research data revealed that there was high level of attentiveness towards policies work related injury within the study setting. These findings suggest that training of health care workers to maintain and enhance their knowledge about bloodborne pathogens and universal precautions could improve their use of universal precautions. Regular training should include the universal precautions, initial biohazard handling, safety policies, safety activities, safety equipment and materials, continuing monitoring and prospective spotlight of medical personnel. This study results is consistent with the study results carried out by Rapiti, et al., (2005), who studied the dental staff adherence toward job related injury.

\section{Acknowledgements}

Appreciation is hereby extended to all the participants and administrators staff at the Selected Dental Clinics, Saudi Arabia.

\section{References}

[1] Norden, C, Rockwell K, Hruska, T, (2008).Safety culture assessment: a tool for improving patient safety in healthcare organizations. West at, Research Blvd, Rockville, MD 20850, USA.

[2] Universal Precautions for Prevention of Transmission of HIV and Other Bloodborne Infections. Accessed 22 December 2008, [http://www.cdc.gov/]

[3] Hutin \&Yuvan: Assessing the burden of disease from sharps injuries to healthcare workers at national and local levels. 2005, Geneva: World Health Organization, Environmental Burden of Disease Series, No 11

[4] Cathrine, Abed Abdullah, Strathdee Steffanie, Scott Paul, Botros Boulos, Safi Naquibullah, et al: HIV, hepatitis C, and hepatitis B infections and associated risk behavior in injection drug users, Kabul, Afghanistan. Emerging Infectious Diseases Journal. 2007, 13: 1327-31.

[5] Hasan Salman, Galai Noya, Thomas David, Zafar Tariq, Ahmed Mohaamad, Strathdee Steffanie: High HCV seroprevalance and HIV drug use risk behaviours among injection drug users in Pakistan. Harm Reduction Journal. 2006, 3: 26-10.1186/1477-7517-3-26.

[6] Saif-u-Rehman, Rasoul Mohammad, Wodak Allex, Claeson Mariam, Friedman Jed, Sayed Ghulam: Responding to HIV in Afghanistan. Lancet. 2007, 370: 2167-9. 10.1016/S0140-6736(07)61911-4. 


\section{International Journal of Science and Research (IJSR) \\ ISSN (Online): 2319-7064}

Index Copernicus Value (2016): 79.57 | Impact Factor (2015): 6.391

[7] Shiao J, Chuang Y-C: Needlestick and sharps injuries among health-care workers in Taiwan. Epidemiology and Infection Journal. 1999, 122: 259-65. $10.1017 /$ S0950268899002186.

[8] Molassiotis Alexander, Eunica Chan, Virene Chan, Becky Ho, Chit-Ying Lai, et al: Nurses' knowledge of and compliance with universal precautions in an acute care hospital. International Journal of Nursing Studies. 2002, 39: 57-63.

[9] Tsakris A, Mandraveli K, Faitatzidou A, Douboyas J, Tourkantonis A: Reported needlestick and sharps injuries among healthcare workers in a Greek general hospital. Occupational Medicine. 1999, 7: 423-6. 10.1093/occmed/49.7.423.

[10] Lacerda RA. Infeccao hospitalar e sua relacao com a evolucao das practicas de assistencia a saude. In: Lacerda RA, ed. Controle de infeccao em centro cirurgico. Sao Paulo: Atheneu, 2003: 9-14.

[11] Lacerda RA, Egry EY. As infeccoes hospitalares e a sua relacao com o desenvolvimento da assistencia hospitalar: reflexoes para analise praticas atuais de controle. Rev Latinoam Enfermagem 1997;5:13-23.

[12] Beltrami EM, Williams IT, Shapiro CN, Chamberland ME. Risk and management of blood-borne infections in health care workers. Clin Microbiol Rev 2000;13(3):385-407.

[13] Gerberding JL. Incidence and prevalence of human immunodeficiency virus, hepatitis B virus, hepatitis C virus, and cytomegalovirus among health care personnel at risk for blood exposure: final report from a longitudinal study. J Infect Dis 1994;170(6):1410-7.

[14] Norden CW, Rockwell K, Hruska E. Epidemiology of accidental needle-puncture wounds in hospital workers. Am J Med Sci 2008;286(1):26-30.

[15] Rapiti E \&Hutin Y. Estimation of the global burden of disease attributable to contaminated sharps injuries among health-care workers. Am J Ind Med 2005;48(6):482-90.

[16] Khuri-Bulos NA, Toukan A, Mahafzah A, et al. Epidemiology of needlestick and sharp injuries at a university hospital in a developing country: a 3-year prospective study at the Jordan University Hospital, 1993 through 1995. Am J Infect Control 1997;25(4):322-9.

[17] Wang FD, Chen YY, Liu CY. Analysis of sharpedged medical-object injuries at a medical center in Taiwan. Infect Control Hosp Epidemiol 2000;21(10):656-8.

[18] Pruss-Ustun A, Rapiti E, Hutin Y. Sharp injuries: global burden of disease from sharp injuries to health care workers Geneva, Switzerland. World Health Organization, 2003.

[19] Fasubaa OB, Onwudiegwu U, et al. Occupational health hazards among health care workers in an obstetrics and gynaecology unit of a Nigerian teaching hospital. J Obstet Gynaecol 2002;22(1):75-8.

[20] Protection against viral hepatitis. MMWR Morb Mortal Wkly Rep 1985;34(22):313-24, 329-35.

[21] Preventing transmission of infection with human Tlymphotropic virus type III/lymphadenopathy-associated virus in the workplace. MMWR Morb Mortal Wkly Rep 1985;34(45):681-6, 691-5.
[22] McCarthy GM. Universal Precautions J Can Dent Assoc 2000;66:556-7.

[23] Update: human immunodeficiency virus infections in health-care workers exposed to blood of infected patients. MMWR Morb Mortal Wkly Rep 1987;36(19):285-9.

[24] Acquired immunodeficiency syndrome (AIDS): precautions for health-care workers and allied professionals. MMWR Morb Mortal Wkly Rep 1983;32(34):450-1.

[25] Garner JS. Hospital Infection Control Practices Advisory Committee. Guideline for isolation precautions in hospitals. Infect Hosp Epidemiol 1996; 17:53-80.

[26] Spire B, Barre-Sinoussi F, Montagnier L, Chermann JC. Inactivation of lymphadenopathy associated virus by chemical disinfectants. Lancet 1984;2(8408):899-901.

[27] Martin LS, McDougal JS, Loskoski SL. Disinfection and inactivation of the human $\mathrm{T}$ lymphotropic virus type III/Lymphadenopathy-associated virus. J Infect Dis 1985;152(2):400-3.

[28] Martin LS, Cort SP, Mozen M, Heldebrant CM, Evatt BL. Thermal inactivation of the acquired immunodeficiency syndrome virus, human $\mathrm{T}$ lymphotropic virus-III/lymphadenopathy-associated virus, with special reference to antihemophilic factor. J Clin Invest 1985;76(2):875-7.

[29] Olowu O, Oluaje E, Kehinde O. Knowledge and practice of universal precautions among final year medical and dental students in the University College of Ibadan. Dokita 2001;28:6-9.

[30] Odujurin OM, Adegoke OA. AIDS: Awareness and blood handling practices of health care workers in Lagos. Nig J Epidl 1995;11(4):425-30.

[31] Palenick C. Strategic planning for infection control. J Canadian Dental Association 2000;66:556-7.

[32] Danchaivijitr S, Tantiwatanapaiboon Y, Chokloikaew S, et al. Universal precautions: knowledge, compliance and attitudes of doctors and nurses in Thailand. J Med Assoc Thai 1995;78 Suppl 2:S112S117.

[33] Twitchell K. Bloodborne pathogens: what you need to know-Part I. Journal of the American Association of Occupational Health Nurses 2003;51:46-7.

[34] Godin G, Naccache H, Morel S, Ebacher MF. Determinants of nurses' adherence to universal precautions for venipunctures. Am J Infect Control 2000;28(5):359-64.

[35] Stein AD, Makarawo TP, Ahmad MFR. A survey of doctors' and nurses' knowledge, attitudes and compliance with infection control guidelines in Birmingham teaching hospitals. Journal work related injury 2003;54:68-73.

[36] Trim JC, Adams D, Elliott TS. Healthcare workers' knowledge of inoculation injuries and glove use. Br J Nurs 2003;12(4):215-21.

[37] Rana JS, Khan AR, Haleem AA, et al. Hepatitis C: knowledge, attitudes and practices among orthopedic trainee surgeons in Pakistan. Ann Saudi Med 2000;20(56):477-9.

[38] Wang H, Fennie K, He G, (2010). A training programme for prevention of occupational exposure to bloodborne pathogens: impact on knowledge, behaviour

\section{Volume 6 Issue 12, December 2017}


and incidence of needle stick injuries among student nurses in Changsha, People's Republic of China. J Adv Nurs 2003;41(2):187-94.

[39] Heinrich J. Occupational Safety: Selected cost and benefit implications of needle stick prevention devices for hospitals (letter to House of Representatives from US General Accounting Office), 2000.

[40] Gerberding JL. Clinical practice. Occupational exposure to HIV in health care settings. $N$ Engl J Med 2003;348(9):826-33.

[41] Connington A. Has the point been made? a needlestick injury awareness survey. Safe Gard Medical 2002.

[42] Alam M. Knowledge, attitude and practices among health care workers on needle-stick injuries. Ann Saudi Med 2002;22(5-6):396-9.

[43] Fawole AO, Sadoh AE, et al. Practice of universal precautions among healthcare workers. J Natl Med Assoc 2006;98(5):722-6.

[44] Jawaid M, Iqbal M, Shahbaz S. Compliance with standard precautions: a long way ahead. Journal of Public Health 2009;38:85-8.

[45] Evanoff B, Kim L, Mutha S, et al. Compliance with universal precautions among emergency department personnel caring for trauma patients. Ann Emerg Med 1999;33(2):160-5.

[46] Gershon RR, Karkashian CD, Grosch JW, et al. Hospital safety climate and its relationship with safe work practices and workplace exposure incidents. Am J Infect Control 2000;28(3):211-220.

[47] Janjua NZ, Razaq M, Chandir S, et al. Poor knowledge-predictor of nonadherence to universal precautions for blood borne pathogens at first level care facilities in Pakistan. BMC Infect Dis 2007;7:81.

[48] Jordan S. Uptake of guidelines to avoid and report exposure to blood and body fluids. J Adv Nurs 2004;46(4):441-52.

Volume 6 Issue 12, December 2017

www.ijsr.net 